\title{
Habitat quality for shallow water fishes in an urban estuary: the effects of man-made structures on growth
}

\author{
Kenneth W. Able ${ }^{1, *}$, John P. Manderson ${ }^{2}$, Anne L. Studholme ${ }^{2}$ \\ ${ }^{1}$ Marine Field Station, Institute of Marine and Coastal Sciences, Rutgers University, 800 Great Bay Blvd., \\ c/o 132 Great Bay Blvd., Tuckerton, New Jersey 08087-2004, USA \\ ${ }^{2}$ NOAA/National Marine Fisheries Service, Northeast Fisheries Science Center, James J. Howard \\ Marine Sciences Laboratory, Sandy Hook, New Jersey 07732, USA
}

\begin{abstract}
Caging experiments were conducted to determine the growth of juvenile fishes as a measure of habitat quality under large pile-supported platforms or piers, in pile fields and in open-water habitat types in shallow areas (average depth 1.1 to $3.9 \mathrm{~m}$ ) in the Hudson River estuary in 1994 . Three $10 \mathrm{~d}$ caging experiments were conducted in June and early July with recently settled winter flounder Pseudopleuronectes americanus (14.3 to $40.1 \mathrm{~mm} \mathrm{SL})$ and 3 experiments of similar duration in July and August with recently settled tautog Tautoga onitis (20.6 to $48.6 \mathrm{~mm}$ TL). For both species, within-experiment instantaneous growth rates in weight $\left(G_{w}{ }^{-1}\right)$ were significantly higher (3-way ANOVA, Tukey's pair-wise test, $p<0.05$ ) in pile field and open-water habitats than under the piers where fish lost weight in all of the experiments. Growth rates for individual winter flounder and tautog reached values as high as $0.09 \mathrm{~d}^{-1}$ and $0.11 \mathrm{~d}^{-1}$, respectively, in open water and pile field habitats. In addition, $G_{w}$ values for both winter flounder and tautog caged under piers were not significantly different $(p>0.017,1$-sided Dunnett test with Bonferroni correction) from those of conspecifics held concurrently in the laboratory without food. These results, as well as related studies of fish distribution and abundance in the same habitats, indicate that habitat quality under the platforms of large piers $\left(>20000 \mathrm{~m}^{2}\right.$ ) is poor for juvenile fishes when compared with nearby pile field and open-water habitat types. As a result, the impacts of these structures should be considered when estuarine shorelines are developed or renovated.
\end{abstract}

KEY WORDS: Habitat quality · Growth · Fishes · Urban estuary · Piers

\section{INTRODUCTION}

Many estuaries in the United States have been subjected to extensive urbanization and shoreline development resulting in poor overall water quality and the destruction of natural habitats (Chambers 1992, Suchanek 1994, Vernberg 1997). In the harbor portion of the New York-New Jersey Harbor Estuary, only $20 \%$ of the original wetland area still exists (Squires 1992) and artificial structures such as large piers and fields of pilings are ubiquitous in the nearshore region (Woodhead 1991). Of the $776 \mathrm{~km}$ of shoreline in the harbor, $75 \%$ consists of artificial structures, including

•E-mail: able@imcs.rutgers.edu bulkheads, rip-rap and large platform structures (piers) and pilings that significantly limit the shallow water habitat available to estuarine animals in this system (Woodhead 1991). It is also well-known that natural shallow-water habitats in other Middle Atlantic Bight estuaries function as nurseries for a variety of fishes (see Able \& Fahay 1998). As water quality improves in the urban reaches of estuaries, as is occurring in the Hudson River estuary (Brosnan \& O'Shea 1996), juvenile stages of fishes may increase their use of available shallow-water habitat. However, it is not known whether shallow habitats in urban estuaries, many of which are characterized by artificial structures, can meet the habitat requirements of the early life history stages of estuarine fishes. 
One approach to assessing habitat 'quality' has been to compare the habitat-specific growth and/or mortality rates of selected species in natural or artificially manipulated habitats of varying complexity (see for example Connell \& Jones 1991, Sogard 1992, Hayse \& Wissing 1996, Able 1999). Results of these studies suggest that complex habitats provide small fishes with refuges as well as ample food resources and thus minimize mortality due to predation while providing for the rapid growth of individuals. Conceivably, complex artificial structures, such as piers and pile fields, could function similarly for small fishes that use the urban reaches of estuaries. However, comparison of the distribution and abundances of young-of-the-year fishes in pile fields and under large piers in the Hudson River estuary suggested that piers were suboptimal habitats (Able et al. 1998). To further test this premise, we conducted caging experiments to measure the relative growth of young-of-the-year winter flounder Pseudopleuronectes americanus and tautog Tautoga onitis under large piers and in pile fields, as well as in relatively unstructured open-water areas in shallow waters of the Hudson River estuary.

\section{MATERIALS AND METHODS}

Study sites. The study area was located in the Hudson River estuary approximately $3 \mathrm{~km}$ north of the Battery, Manhattan, New York, USA, at approximately $40^{\circ} 44^{\prime} \mathrm{N}, 74^{\circ} 01^{\prime} \mathrm{W}$ (Fig. 1) where tidal range averages $1.4 \mathrm{~m}$. Three types of subtidal habitats were selected for the growth experiments along both the New York and New Jersey shorelines: (1) under pile-supported platforms (under piers), (2) in pile fields, which consisted of arrays of pile supports (pilings) left intact after the removal of pier platforms, and (3) in open-water areas between pile fields and piers (Table 1). All of the study sites were less than $1.3 \mathrm{~km}$ apart. Replicate stations $(n=5)$ were established in each of the above

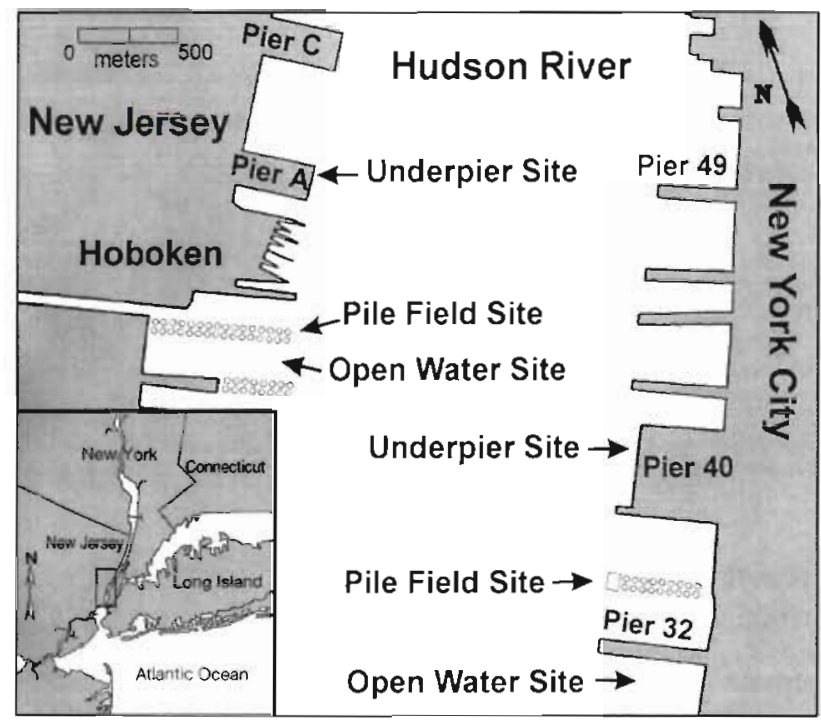

Fig. 1. Location of the study area and study sites in the Hudson River estuary at approximately $40^{\circ} 44^{\prime} \mathrm{N}, 74^{\circ} 01^{\prime} \mathrm{W}$

habitat types $(\mathrm{n}=3)$ on each side of the river $(\mathrm{n}=2)$ for a total of 30 stations.

The under-pier habitats were situated beneath 2 large $\left(>20000 \mathrm{~m}^{2}\right.$ ) concrete piers; in New Jersey at Port Authority Pier A and in New York at Marine and Aviation Pier 40 (Fig. 1). The stations $(n=5)$ at each pier site were established at least $55 \mathrm{~m}$ from their edges under the approximate center of each pier. The 2 pile field sites were large rectangular arrays of pile supports (>6000 $\mathrm{m}^{2}$ ) located approximately $300 \mathrm{~m}$ to the south of Pier 40 in New York and about $450 \mathrm{~m}$ south of Pier A in New Jersey (Table 1, Fig. 1). Stations at both sites were adjacent to pilings and approximately $100 \mathrm{~m}$ from shore. The open-water sites in both New Jersey and New York were situated in large (>13500 $\mathrm{m}^{2}$ ) areas at least $25 \mathrm{~m}$ from adjacent pile fields and/or piers and $75 \mathrm{~m}$ from the nearest shore (Table 1, Fig 1).

Table 1. Physical characteristics of the 6 study sites in the Hudson River estuary in 1994. See Fig. 1 for locations

\begin{tabular}{|c|c|c|c|c|c|c|c|}
\hline $\begin{array}{l}\text { Location/ } \\
\text { habitat type }\end{array}$ & $\begin{array}{c}\text { Area } \\
\left(\mathrm{m}^{2} \times 10^{3}\right)\end{array}$ & $\begin{array}{c}\text { Depth (m) } \\
\text { mean (range) }\end{array}$ & $\begin{array}{l}\text { Light on bottom } \\
\left\{\mu E m^{-2} s^{-1} \pm S E\right\}\end{array}$ & $\begin{array}{l}\text { Temperature } \\
\text { range }\left({ }^{\circ} \mathrm{C}\right)\end{array}$ & $\begin{array}{l}\text { Salinity } \\
\text { range }(\%)\end{array}$ & $\begin{array}{l}\text { Dissolved oxygen } \\
\text { range (mg l-1) }\end{array}$ & $\begin{array}{c}\text { Sediment grain size } \\
(\% \text { silt-clay) } \\
\text { Mean (range) }\end{array}$ \\
\hline \multicolumn{8}{|l|}{ New York } \\
\hline Under pier & 89.5 & $1.7(1.4-2.1)$ & 0 & $12.2-26.2$ & $7.0-23.8$ & $2.9-9.1$ & $95.5(9.5 .1-95.9)$ \\
\hline Open water & 41.1 & $3.9(2.8-4.5)$ & $15 \pm 8$ & $10.7-26.3$ & $13.6-25.6$ & $0.2-7.1$ & $98.4(97.8-98.9)$ \\
\hline Pile field. & 13.5 & $1.1(0.7-1.6)$ & $40 \pm 40$ & - & - & - & $67.7(51.7-93.8)$ \\
\hline \multicolumn{8}{|l|}{ New Jersey } \\
\hline Under pier & 21.3 & $1.3(1.0-1.5)$ & 0 & $12.4-26.4$ & $6.3-23.7$ & $3.6-10.9$ & $92.8(90.2-94.8)$ \\
\hline Open water & 13.6 & $1.4(1.1-1.7)$ & $15 \pm 1$ & - & - & - & $93.0(91.1-94.2)$ \\
\hline Pile field & 6.1 & $1.7\{1.4-2.1\}$ & $9 \pm 7$ & $11.9-26.4$ & $6.7-25.3$ & $0.6-9.0$ & $84.6(74.7-92.6)$ \\
\hline
\end{tabular}


Physical characteristics. Temperature, salinity and dissolved oxygen were recorded using 2 Hydrolab Datasonde 1 and 2 Datasonde 3 multi-probe data loggers deployed under both piers and the New Jersey pile field and the New York open water sites (Table 1). The data loggers were attached to cinder blocks deployed on the bottom such that hourly measurements were recorded approximately $25 \mathrm{~cm}$ above the substrate. Light levels were recorded at the sites with a Licor spherical Quanta sensor 3 times (09:00 h, June 1; 11:00 h, June 20; 14:00 h, August 10) on the bottom (Table 1). Station depths were measured to the nearest $4 \mathrm{~cm}$ with a sounding lead 5 times during the experiments. Depths were standardized to mean low water (MLW) by applying corrections for tidal heights at the Battery, New York (U.S. Department of Commerce 1992, 1993). Sediment grain size was determined using one core $(3 \mathrm{~cm}$ diameter) from each of 3 box cores collected at stations selected at random at each site during the first week of August ( 6 sites $\times 3$ cores $=18$ cores). Particle size distribution of the sediment mineral fraction was measured based on the standard sieving procedures of Folk (1980).

Caging techniques. Caging experiments were performed to determine the relative habitat-specific growth of recently settled winter flounder and tautog in the 3 habitat types. These 2 species were selected for these experiments because they have been shown to exhibit independent growth responses to different habitat types (Sogard 1992) and they occurred naturally in the study area (Able et al. 1998). The cages were constructed of rectangular steel with frames measuring $0.85 \times 0.85 \times 0.45 \mathrm{~m}$ and lined with $3 \mathrm{~mm}$ nylon mesh bags $(0.75 \times 0.75 \times 0.40 \mathrm{~m})$ equipped with a zippered top and secured tightly to the frames. This ensured that fish were retained but allowed sediment and potential prey to penetrate into the cages after the latter had been lowered to the substrate. Observations made with underwater cameras at a site with sedi-

Table 2. Details of caging experiments conducted with recently settled winter flounder and tautog in the Hudson River estuary. Lengths of winter flounder and tautog are reported as standard length (SL) and total length (TL), respectively

\begin{tabular}{|lccccc|}
\hline \multirow{2}{*}{$\begin{array}{l}\text { Experiment } \\
\text { dates }\end{array}$} & \multicolumn{2}{c}{$\begin{array}{c}\text { Initial size } \\
\text { mean (range) }\end{array}$} & \multicolumn{2}{c|}{$\begin{array}{c}\text { Number } \\
\text { deployed }\end{array}$} & $\begin{array}{c}\text { Fish re- } \\
\text { covered }\end{array}$ \\
& Length (mm) & Weight (g) & Cages & Fish & $(\%)$ \\
\hline Winter flounder & & & & & \\
1. Jun 3-13 & $22.0(14.3-29.4)$ & $0.2(0.1-0.4)$ & 30 & 90 & 61 \\
2. Jun 17-27 & $22.6(19.9-37.5)$ & $0.3(0.1-0.9)$ & 30 & 90 & 94 \\
3. Jul 1-11 & $30.6(22.5-40.1)$ & $0.5(0.2-1.1)$ & 30 & 90 & 81 \\
Tautog & & & & & \\
1. Jul 22-Aug 1 & $27.9(21.5-48.6)$ & $0.3(0.1-1.5)$ & 30 & 86 & 57 \\
2. Aug 5-15 & $35.2(22.4-47.8)$ & $0.6(0.1-1.5)$ & 30 & 89 & 94 \\
3. Aug 19-29 & $32.0(20.6-43.3)$ & $0.4(0.1-1.0)$ & 30 & 89 & 82 \\
\hline
\end{tabular}

ments similar to the study sites (the boat basin at Rutgers University Marine Field Station, Tuckerton, New Jersey, USA), showed that sediment penetrated through the mesh at the bottom of the cage at deployment and 1 to $2 \mathrm{~cm}$ of sediment covered the bottoms of most cages when they were retrieved after $10 \mathrm{~d}$.

Three $11 \mathrm{~d}$ experiments (10 d in field) were conducted with each species (Table 2). The timing of the experiments and choice of species were determined by the seasonal availability of wild fish. Thus, experiments performed in the early summer were conducted with winter flounder, while tautog were used from mid- through late summer (Table 2). Both winter flounder and tautog were collected with a $30 \mathrm{~m}$ haul seine or $1 \mathrm{~m}$ beam trawl in Sandy Hook Bay, New Jersey, part of the New York-New Jersey Harbor Estuary. Captured fish were transported to the James J. Howard Marine Sciences Laboratory, Highlands, New Jersey and held less than $7 \mathrm{~d}$ in $637 \mathrm{I}$ aquaria provided with a $2 \mathrm{~cm}$ substrate of washed sand and filtered, flowthrough seawater (salinity 24 to $27 \%$, temperature 15 to $24^{\circ} \mathrm{C}$ ). Both species were fed ad libitum on frozen brine shrimp. Artemia sp., throughout the holding periods.

Before the start of each experiment, randomly selected fish ( $\mathrm{n}=90$ ) were individually marked with a subcutaneous injection of nontoxic acrylic paint (Createx) to allow recognition of individuals at the end of each experiment. The marked fish were held for a $24 \mathrm{~h}$ recovery period, then lightly blotted, weighed $\pm 0.01 \mathrm{~g}$ ) and measured $( \pm 0.1 \mathrm{~mm}$ standard length [SL] for winter flounder and total length [TL] for tautog). Fish were then selected at random and placed in groups of 3 in perforated containers in holding aquaria for an additional 18 h recovery period without food. The handling procedures were similar for both species except that tautog were briefly ( $<60 \mathrm{~s}$ ) anesthetized with MS222 (3-aminobenzoic acid ethyl ester) before weighing. For transport to the study sites, the fish were transferred to labeled 1 l jars with mesh covers, which were placed in a 4751 cooler filled with aerated seawater. At the study sites, 3 randomly selected fish were introduced into each of the individual cages, which were then lowered to the bottom substrate at each of the 30 stations ( 3 fish $\times 30$ stations, $\mathrm{n}=90$; note that in the tautog experiments, mortality occurred during transport so that only 86 to 89 fish were deployed; Table 2). After $10 \mathrm{~d}$, the cages were retrieved, the fish carefully removed from each cage, transferred to labeled jars, and transported to the laboratory where individuals 
were reweighed and remeasured to determine changes in length and weight. The sizes of fish caged varied with each experiment and reflected their temporal availability in natural populations (Table 2 ).

Laboratory experiments on winter flounder $(n=45$; 15.4 to $41.1 \mathrm{~mm} \mathrm{SL}$ ) and tautog ( $\mathrm{n}=47 ; 20.6$ to $45.1 \mathrm{~mm}$ TL) were performed at the same time as each of the caging experiments to determine changes in growth and survival when held for a similar time period (11 d) without food. For each of these laboratory experiments, 5 groups of 3 fish each were marked, weighed and measured as described above and placed in $20 \mathrm{l}$ jars held in laboratory seawater aquaria, then reweighed and remeasured at the end of the holding period. Temperature, salinity, and photoperiod approximated natural conditions at the study sites.

Experiments were also performed (in early July) to determine the rate of decomposition of fish that might have died in cages in the study habitats. Winter flounder ( $\mathrm{n}=10,21$ to $40 \mathrm{~mm}$ SL) were killed with MS-222, transported to the study area and individually introduced into cages $(0.1 \times 0.1 \times 0.1 \mathrm{~m}, 3 \mathrm{~mm}$ mesh) deployed on the substrate in the New York under pier ( $n=5$ cages) and open water sites ( $n=5$ cages). The cages were retrieved every $24 \mathrm{~h}$ and the extent of tissue decomposition was recorded. At both sites the tissues of sacrificed fish were undetectable within $48 \mathrm{~h}$ of initial deployment.

Statistical analysis. The growth increments for caged winter flounder and tautog were calculated as instantaneous growth rates $(G)$ using the formula:

$$
G=\frac{\ln \left(m_{1} / m_{0}\right)}{t_{1}-t_{0}}
$$

where $m_{0}$ and $m_{1}$ are the initial and final weight in $g$, or the initial and final standard (winter flounder) or total (tautog) length in $\mathrm{mm}$ and $t_{0}$ and $t_{1}$ are the initial and final time in days (Ricker 1975). Comparison of growth rates between habitats was made with weight as the growth parameter because weight is considered more sensitive than length over short time intervals (Weatherly 1972). The initial day of an experiment was the day on which the fish were measured and the final day that on which they were recovered and remeasured $\left(t_{1}-t_{0}=11 \mathrm{~d}\right)$. The growth rates of individual fish recovered from each cage were averaged $\left(\bar{G}_{\mathrm{w}}\right.$ cage $^{-1}$ ) before the application of statistical tests to ensure that growth observations at the study sites were independent (Hurlbert 1984).

For each species, a 3-way analysis of covariance (ANCOVA) with experiment ( $\mathrm{n}=3$ for each species), location ( $n=2$; i.e. New York, New Jersey), and habitat type ( $\mathrm{n}=3$; i.e. under pier, pile field, and open water) as fixed and crossed main effects, and the initial weight of the fish as the covariate, were applied to the data to identify significant differences in the growth of caged fish. As the covariate was not a significant source of variation in tests for each species ( $p>0.05$; Wilkerson 1997), 3-way analysis of variance (ANOVA) tests were performed. Tukey's tests were used for pairwise comparisons and Levene's tests for homogeneity of variance were used to test for homoscedasticity (Wilkerson 1997).

Statistical differences in the growth of fish caged at the study sites and fish held in the laboratory without food were tested using Dunnett's 1-sided test separately for each experiment. In order to reduce the probability of committing a Type $I$ error as the result of performance of multiple tests, we adjusted the probabilities using a Bonferroni correction. For detecting significant differences in growth rate, 0.017 was used as the $p$-value.

\section{RESULTS}

\section{Physical characteristics}

Station depths were $<2.2 \mathrm{~m}$ deep (MLW) at all sites except the New York open water sites where stations were somewhat deeper $\left(<4.5 \mathrm{~m}_{i}\right.$ Table 1$)$. Temperatures and salinities exhibited seasonal and diel fluctuations typical of Middle Atlantic Bight estuaries with significant tidal and riverine influences. Average temperatures were lowest during the first winter flounder experiment (early June 1994) and peaked at $26^{\circ} \mathrm{C}$ in late July during the first tautog experiment before declining in the early fall. Although salinities as low as 6 to $7 \%$ were recorded in early June, the typical range was from 13 to $26 \%$ with occasional higher salinities measured at the deeper New York open water site. Both temperature and salinity exhibited tidal variations (mean change $=1.4^{\circ} \mathrm{C}$ and $5 \%$ ).

Other physical parameters including bottom light intensities and sediment grain size, varied by habitat type (Table 1). Average light intensities were low in the open water and pile field sites, ranging from 9 to $40 \mu \mathrm{E} \mathrm{m}^{-2} \mathrm{~s}^{-1}$ on the bottom (Table 1). In contrast, there was no light measured under the piers on the bottom. Fine sediments $(<63 \mu \mathrm{m}$, silts and clays) were characteristic of under pier and open water habitats $1>90 \%$ fine fraction), while sediment samples collected in the pile fields had a significantly lower proportion of fine sediments $(51.7$ to $93.8 \%$ fine fraction: Kruskal-Wallis test, $W=13.5$, df $=5, p<0.05$, Table 1 ) and often contained fragments of concrete and wood.

Dissolved oxygen ranged up to relatively high levels at all sites at which the data loggers were deployed (Table 1). However, oxygen concentrations as low as 
$0.2 \mathrm{mg} \mathrm{l}^{-1}$ were recorded in the New York open water site and $0.6 \mathrm{mg} \mathrm{l}^{-1}$ in the New Jersey pile field. Hypoxic events (i.e. $<2.5 \mathrm{mg} \mathrm{l}^{-1}$ ) occurred primarily in July and August and extended from 25 to $75 \%$ of a $24 \mathrm{~h}$ period. In contrast, dissolved oxygen levels at both under-pier sites never fell below $2.9 \mathrm{mg} \mathrm{l}^{-1}$ (Table 1).

\section{Habitat-specific growth}

\section{Winter flounder}

Recovery of winter flounder from the 3 experiments averaged $79 \%$, ranging as high as $94 \%$ in one experiment (Table 2). Recovery of fish from the pile field $(90.0 \%)$ and open-water $(82.1 \%)$ habitats was higher than from under the piers $(59.9 \%)$.

Growth rates varied among experiments and habitats. Individual growth rates $\left(G_{w}\right)$ of winter flounder ranged from -0.038 to $0.087 \mathrm{~d}^{-1}$, the absolute increase in weight over the $11-\mathrm{d}$ period ranging from -0.16 to $0.60 \mathrm{~g}$. Growth rates in length $\left(G_{1}\right)$ followed trends in weight, ranging from -0.003 to $0.026 \mathrm{~d}^{-1}(-0.89$ to $7.85 \mathrm{~mm}$ over $11 \mathrm{~d})$. Growth rates, based on mean growth in weight of all fish recovered from each cage $\left(\bar{G}_{\mathrm{w}}\right.$ cage $\left.^{-1}\right)$, were comparable to individual rates ranging from -0.027 to $0.076 \mathrm{~d}^{-1}$. Changes in length $(\bar{x}$ cage $^{-1} \mathrm{~d}^{-1}$ ) ranged from -0.06 to $0.53 \mathrm{~mm} \mathrm{~d}^{-1}$. The fastest growth was recorded in the first experiment with rates generally declining in subsequent experiments (Fig. 2a,b,c).

While all the main effects as well as the interactions of Experiment $\times$ Habitat and Location $\times$ Habitat were significant sources of variation in growth for caged winter flounder, habitat type accounted for the largest proportion of the variation (3-way ANOVA, Table 3). Much of the habitat-related variation was the result of poor and consistently negative growth of fish caged in the under-pier sites (Fig. 2a,b,c). Growth rates under the piers were significantly $(p<0.05)$ lower than rates measured in the pile field and open-water sites except in Expt 3 in which growth was also poor in the New York pile field (Table 4, Fig. 2a,b,c).

Fish caged under the piers lost weight in all 3 experiments with $G_{\mathrm{w}}\left(\bar{x}\right.$ cage $\left.^{-1}\right)$ ranging from -0.022 to $-0.009 \mathrm{~d}^{-1}$. Changes in length ranged from -0.07 to $0.02 \mathrm{~mm} \mathrm{~d}^{-1}$. In addition, $G_{\mathrm{w}}$ values for fish caged under the piers were not significantly different $(p>$ $0.017,1$-sided Dunnett test with Bonferroni correction) from those of fish held in the laboratory without food during any of the 3 experiments (Table 4). Starved fish lost weight with $G_{\mathrm{w}}\left(\bar{x}\right.$ group $\left.^{-1}\right)$ ranging from -0.082 to $-0.015 \mathrm{~d}^{-1}$. Changes in length ranged from -0.09 to $0.02 \mathrm{~mm} \mathrm{~d}^{-1}$. Survival of starved fish in the laboratory averaged $86.7 \%$.

While winter flounder grew at relatively fast rates in the pile field and open water sites, consistent habitatspecific differences between these 2 habitat types were
Fig. 2. Mean instantaneous growth rates in weight in $\left(G_{\mathrm{w}} \mathrm{d}^{-1} \pm\right.$ 2 standard errors) for caging experiments in the Hudson River estuary for winter flounder for (a) Expt 1, (b) Expt 2 and (c) Expt 3 and tautog for (d) Expt 1, (e) Expt 2 and (f) Expt 3. N indicates the number of cage means composing the mean value at the site. See Table 2 for the initial size of fish

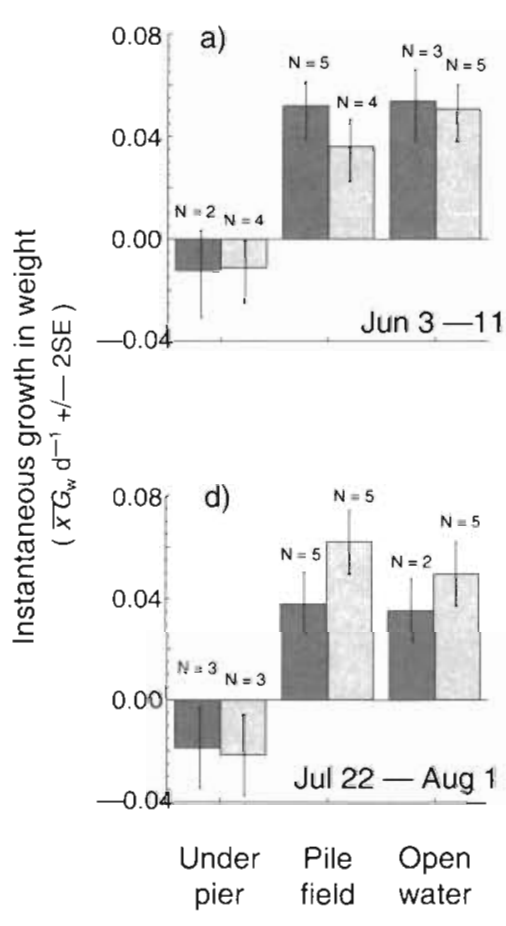

Winter flounder

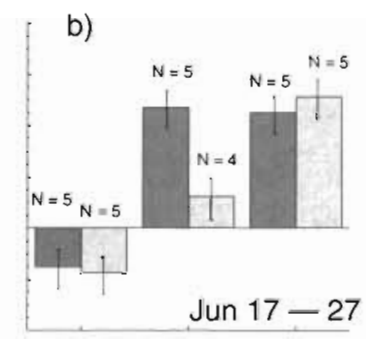

c)

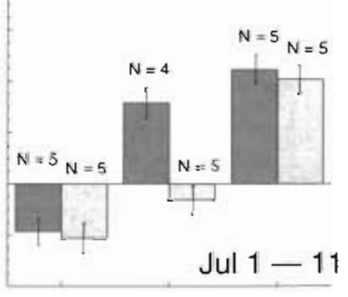

New York

New Jersey

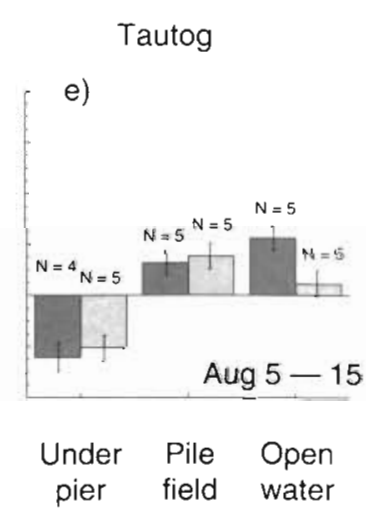

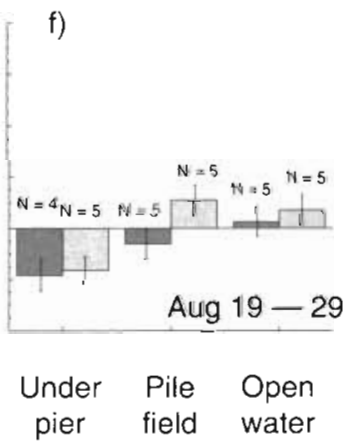


Table 3 . Results of 3 -way ANOVA test on the instantaneous growth $\left(\vec{G}_{w}\right.$ cage $^{-1}$ ) of winter flounder and tautog caged in the Hudson River estuary. $\cdots<0.001, \cdots<0.01, \cdot<0.05$, ns $=$ not significant

\begin{tabular}{|c|c|c|c|}
\hline $\begin{array}{l}\text { Species/ } \\
\text { source of variation }\end{array}$ & $\begin{array}{l}\text { Degrees } \\
\text { of freedom }\end{array}$ & $\begin{array}{l}\text { Mean } \\
\text { square }\end{array}$ & $F$ \\
\hline \multicolumn{4}{|l|}{ Winter flounder } \\
\hline Expt & 2 & 0.16591 & $20.53990^{\cdots}$ \\
\hline Location & 1 & 0.20350 & $25.19366^{\cdots}$ \\
\hline Habitat & 2 & 2.62988 & $325.58592^{\cdots} \cdots$ \\
\hline Expt $\times$ Location & 2 & 0.01178 & $1.45853 \mathrm{~ns}$ \\
\hline Expt $\times$ Habitat & 4 & 0.03634 & $4.49930^{\cdots}$ \\
\hline Location $\times$ Habitat & 2 & 0.18060 & $22.35815^{\cdots} \cdot$ \\
\hline Expt $\times$ Location $\times$ Habitat & 4 & 0.01286 & $1.59193 \mathrm{~ns}$ \\
\hline Error & 63 & 0.00808 & \\
\hline \multicolumn{4}{|l|}{ Tautog } \\
\hline Expt & 2 & 0.00553 & $66.11275^{\cdots}$ \\
\hline Location & 1 & 0.00057 & $6.86319^{\circ}$ \\
\hline Habitat & 2 & 0.01409 & $168.39779 \cdots$ \\
\hline Expt $\times$ Location & 2 & 0.00046 & $5.48834{ }^{\circ}$ \\
\hline Expt $\times$ Habitat & 4 & 0.00144 & $17.21792 \cdots$ \\
\hline Location $\times$ Habitat & 2 & 0.00047 & $5.65536^{\bullet \cdot}$ \\
\hline Expt $\times$ Location $\times$ Habitat & 4 & 0.00021 & $2.52559^{\circ}$ \\
\hline Error & 66 & 0.00008 & \\
\hline
\end{tabular}

Expts 2 and 3, this site was subject to disturbance due to renovation of the pilings

\section{Tautog}

Recovery levels of tautog were generally similar to those for winter flounder, averaging $78 \%$, with $94 \%$ and $82 \%$ of the deployed fish recovered in each of the last 2 experiments, respectively (Table 2). Also, as was characteristic of the winter flounder experiments, recovery of tautog from the pile field $(90 \%)$ and open water $(82 \%)$ habitats was higher than from under the piers $(60 \%)$.

Growth rates of tautog also varied among experiments and habitats. Individual growth rates $\left\{G_{w}\right\}$ of tautog ranged from -0.047 to $0.108 \mathrm{~d}^{-1}$ (absolute changes in weight ranging from -0.20 to $0.96 \mathrm{~g}$ over the $11 \mathrm{~d}$ period). Growth rates in length $\left(G_{1}\right)$ ranged from -0.013 to $0.026 \mathrm{~d}^{-1}$ (changes in length ranging from -3.87 to $10.62 \mathrm{~mm}$ ).

not detected. Growth rates in the New Jersey pile field and the New York and New Jersey open-water sites were not significantly different $(p>0.05)$ in any of the experiments (Table 4, Fig. 2a,b,c). Although growth was significantly lower $(\mathrm{p}<0.05)$ in the New York pile field than in the other pile field and open-water sites in
Mean growth rates $\left(\bar{G}_{w}\right.$ cage $\left.^{-1}\right)$ were comparable to individual rates and ranged from -0.031 to $0.088 \mathrm{~d}^{-1}$ with changes in length ranging from -0.26 to $0.76 \mathrm{~mm}$ $\mathrm{d}^{-1}$ (Fig. 2d,e,f). By the last experiment, although growth was positive at half of the sites, overall average growth was negative (Table 4, Fig. 2f).

Table 4. Results of Tukey's pair-wise comparison tests for differences in the mean instantaneous growth in weight $\left(\bar{G}_{\mathrm{w}}\right.$ cage $\left.\mathrm{e}^{-1}\right)$ of winter flounder and tautog caged in the Hudson River estuary and for differences in growth of fish at the study sites and fish starved in the laboratory (1-sided Dunnett test) during 6 experiments. Sites are listed in order of decreasing growth rates with mean $G_{v}$ listed below each site. Means sharing the same letter ${ }^{a, b, c}$ not statistically different $(p>0.05)$ in Tukey's pair-wise tests. Only within-experiment comparisons are included. With the exception of under-pier sites, growth rates were significantly higher $(p<0.017)$ at the study sites than for fish starved in the laboratory in all experiments ( 1 -sided Dunnett test with Bonferroni correction). $J F=$ New Jersey pile field $; \mathrm{JO}=$ New Jersey open water; $\mathrm{JP}=$ New Jersey under pier; $Y F=$ New York pile field; $Y O=$ New York open water; YP = New York under pier; Starved fish $=$ fish held in the laboratory without food

\begin{tabular}{|c|c|c|c|c|c|c|c|}
\hline Trial date & \multicolumn{6}{|c|}{ Study sites in order of decreasing growth $\left(G_{w}\right)$} & Starved fish \\
\hline $\begin{array}{l}\text { Winter flounder } \\
\text { Jun } 3-13\end{array}$ & $\begin{array}{c}J O^{\circ} \\
0.0539\end{array}$ & $\begin{array}{c}J^{\mathrm{a}} \\
0.0520\end{array}$ & $\begin{array}{r}\mathrm{YO}^{\mathrm{a}} \\
0.0507\end{array}$ & $\begin{array}{r}Y^{a} \\
0.0361\end{array}$ & $\begin{array}{c}Y P^{b} \\
-0.0112\end{array}$ & $\begin{array}{c}J P^{\mathrm{b}} \\
-0.0123\end{array}$ & -0.0328 \\
\hline Jun $17-27$ & $\begin{array}{r}\mathrm{YO}^{\mathrm{a}} \\
0.0512\end{array}$ & $\begin{array}{c}J F^{a} \\
0.0470\end{array}$ & $\begin{array}{c}\mathrm{JO}^{\mathrm{a}} \\
0.0449\end{array}$ & $\begin{array}{c}Y F^{b} \\
0.0123\end{array}$ & $\begin{array}{c}J P^{c} \\
-0.0152\end{array}$ & $\begin{array}{c}Y P^{C} \\
-0.0174\end{array}$ & -0.0206 \\
\hline Jul $1-11$ & $\begin{array}{c}3 \mathrm{O}^{\mathrm{a}} \\
0.0445\end{array}$ & $\begin{array}{c}Y^{\mathrm{a}} \\
0.0408\end{array}$ & $\begin{array}{c}\mathrm{JF}^{\mathrm{a}} \\
0.0315\end{array}$ & $\begin{array}{c}Y F^{b} \\
-0.0063\end{array}$ & $\begin{array}{c}J P^{b c} \\
-0.0180\end{array}$ & $\begin{array}{c}Y P^{c} \\
-0.0213\end{array}$ & -0.0219 \\
\hline $\begin{array}{l}\text { Tautog } \\
\text { Jul 22-Aug } 1\end{array}$ & $\begin{array}{c}Y F^{d} \\
0.0621\end{array}$ & $\begin{array}{c}\mathrm{YO}^{a b} \\
0.0496\end{array}$ & $\begin{array}{c}\mathrm{JF}^{\mathrm{b}} \\
0.0379\end{array}$ & $\begin{array}{c}\mathrm{JO}^{\mathrm{b}} \\
-0.0353\end{array}$ & $\begin{array}{c}J P^{\mathrm{c}} \\
-0.0187\end{array}$ & $\begin{array}{c}Y P^{\mathrm{c}} \\
-0.0216\end{array}$ & -0.0227 \\
\hline Aug 5-15 & $\begin{array}{c}3 \mathrm{O}^{\circ} \\
0.0224\end{array}$ & $\begin{array}{c}Y F^{d} \\
0.0153\end{array}$ & $\begin{array}{c}\mathrm{JF}^{\mathrm{d}} \\
0.0127\end{array}$ & $\begin{array}{r}\mathrm{YO}^{\mathrm{a}} \\
0.0044\end{array}$ & $\begin{array}{c}Y P^{b} \\
-0.0206\end{array}$ & $\begin{array}{c}J P^{b} \\
-0.0242\end{array}$ & -0.0227 \\
\hline Aug $19-29$ & $\begin{array}{r}Y^{d} \\
0.0111\end{array}$ & $\begin{array}{c}Y O^{*} \\
0.0071\end{array}$ & $\begin{array}{r}J^{a b b} \\
0.0024\end{array}$ & $\begin{array}{c}J F^{a b} \\
-0.0061\end{array}$ & $\begin{array}{c}Y P^{b} \\
-0.0163\end{array}$ & $\begin{array}{c}J P^{b} \\
-0.0184\end{array}$ & -0.0303 \\
\hline
\end{tabular}


Habitat-specific growth patterns of tautog caged in the Hudson River estuary were generally similar to those shown by winter flounder (Fig. 2). While all the main effects and interactions were significant (3-way ANOVA, Table 3), habitat type, followed by experiment, accounted for the largest proportion of the variation.

With the exception of the last experiment in which growth of tautog was relatively poor at all sites, tautog held under the piers showed significantly lower growth than fish held in the pile field and open water habitats ( $p<0.05$, Table 4, Fig. 2d,e,f). Tautog consistently lost weight under the piers with growth rates $\left(G_{\mathrm{w}}\right)$ ranging from -0.031 to $-0.01 \mathrm{~d}^{-1}$. Changes in length ranged from -0.26 to $0.02 \mathrm{~mm} \mathrm{~d}^{-1}$. These growth rates under the piers were not significantly different from those of tautog held concurrently in the laboratory without food ( $p>0.017,1$-sided Dunnett test, Table 4$)$. Growth rates of starved fish $\left(\bar{G}_{w}\right.$ group $\left.^{-1}\right)$ ranged from -0.075 to $-0.001 \mathrm{~d}^{-1}$ (changes in length ranged from -0.10 to $0.01 \mathrm{~mm} \mathrm{~d}^{-1}$ ). Survival of the starved fish in the laboratory averaged $65.2 \%$.

As noted above, with the exception of the tautog caged in the New Jersey pile field in the last experiment, growth rates of fish in the pile fields and open water areas were positive and higher than those of starved fish (Table 4, Fig. 2d,e,f). However, clear and consistent habitat-specific differences in growth between these 2 habitat types were not evident.

\section{DISCUSSION}

Several lines of evidence indicated that habitat quality for recently settled winter flounder and tautog was poor under the centers of piers in the Hudson River estuary. First, both species consistently lost weight under the piers and growth rates were generally significantly lower under the piers than in adjacent pile field and open-water areas. Second, rates of weight loss for fish under the piers were not significantly different from those exhibited by fish starved in the laboratory. Third, fewer fish were recovered from cages deployed under the piers than in the pile field and open-water habitat sites, suggesting that survival rates for caged fish were also lower under the piers than in the other 2 habitat types. Fourth, the values for growth (both weight and length) are consistent for both species in all habitats (Able et al. 1996). Habitat characteristics, which influence the growth and survival of juvenile fishes, are important determinants of habitat quality (Sogard 1990, Hoss \& Thayer 1993, Gibson 1994, Able 1999). Thus these measures, independently and together, indicate that large pile-supported platforms (i.e. piers such as those in the lower Hudson
River estuary) are poor habitats for these 2 species and perhaps other juveniles fishes.

The extent of weight loss, which approximated that of starved fish in the laboratory, and the possibility of lower survival for fish caged under the piers suggest that even if appropriate prey species were available for young-of-the-year winter flounder and tautog, e.g. primarily small crustaceans, and polychaetes (Pearcy 1962, Grover 1982, Sogard 1992, Dorf 1994), these species were unable to feed effectively. While examination of food habits and predator-prey interactions were not included in the present study, previous benthic grab surveys under and in open water adjacent to Pier 76, a large pile-supported pier just north of Pier 40 , indicated that some suitable prey species are found in this habitat type (Stoecker et al. 1992).

One of the factors that could influence feeding ability may be related to light intensity, which was zero on the bottom under the centers of the 2 piers close to the substrate where the cages were deployed. Both winter flounder and tautog are primarily visual predators (Olla et al. 1969. Deacutis 1982) and it may be that, given the absence of light under the piers, neither species was able to feed efficiently. The foraging efficiencies of most predatory fishes that rely on vision to locate prey are reduced at light levels less than 10 lux or $0.01 \mu \mathrm{E} \mathrm{m}^{-2} \mathrm{~s}^{-1}$ (Blaxter 1970). The light levels under the piers were below the visual thresholds of a number of fish species including Cynoscion regalis (Grecay \& Targett 1996), Hippocampus erectus (James \& Heck 1994) and Lepomis macrochirus (Vinyard \& O'Brien 1976). Although some visual predators are able to feed in darkness using alternative modes of perception, feeding rates sufficient for growth usually demand high prey concentrations and encounter rates (Grecay \& Targett 1996).

Although differences in the growth of fish between the pile fields and open-water areas were typically small within experiments, there were often marked differences in growth between experiments. Growth rates were invariably highest in the first experiment conducted with each species. However since growth rates are often inversely related to size in young fish (Sogard 1992, Veer et al. 1994) this could simply reflect faster growth by the smaller fish used in these experiments. While seasonal variability in levels of dissolved oxygen occurred in some of the study sites and could have influenced growth rates (Hughes 1981), low dissolved oxygen was probably not a critical factor for fish held under the piers where dissolved oxygen exceeded $2.8 \mathrm{mg} \mathrm{l}^{-1}$

Winter flounder and tautog caged in the Hudson River estuary pile field and open water sites grew at rates that were within the range of those measured simultaneously with open-bottomed cages in natural 
habitats (Zostera marina and Ulva lactuca beds and sand) unvegetated in the nearby Navesink River, New Jersey (B. Phelan unpubl data), which are important nursery areas for winter flounder (Scarlett 1991, Phelan 1992) and tautog (Manderson \& Phelan unpubl. data). In similar experiments instantaneous growth rates $\left(\bar{G}_{w}\right.$ cage $\left.^{-1}\right)$ of winter flounder in Navesink River habitats were as high as $0.108 \mathrm{~d}^{-1}$ and for tautog $0.073 \mathrm{~d}^{-1}$ (B. Phelan, unpubl. data). In the open water and pile-field sites of the Hudson River estuary, maximum growth $\left(\bar{G}_{\mathrm{w}}\right.$ cage $\left.^{-1}\right)$ was $0.076 \mathrm{~d}^{-1}$ for winter flounder and $0.088 \mathrm{~d}^{-1}$ for tautog. While differences in temperature, prey availability and other factors can influence these growth rates, these data suggest that within the urban reaches of the estuary some shallowwater habitats, including those defined by artificial structures (e.g. pile fields) contain food resources and provide environmental conditions that support relatively rapid growth for early life stages of these 2 species.

Nevertheless, growth of young-of-the-year winter flounder was lower in the Hudson River estuary than for fish held at the same time in open bottom cages in the Great Bay/Little Egg Harbor system in southern New Jersey, which is a relatively unaltered estuary (Psuty et al. 1993). Using changes in length for comparison, the maximum growth rate $\left(\bar{G}_{1}\right.$ cage $\left.^{-1}\right)$ of winter flounder in this system was nearly twice as high $\left(G_{1}\right.$ $=0.045 \mathrm{~d}^{-1}$ ) (Able \& Hagan unpubl. data) as the rate for fish in the Hudson River estuary $\left(G_{1}=0.024 \mathrm{~d}^{-1}\right)$ and one and a half times higher than for fish held in the Navesink River $\left(G_{1}=0.030\right.$ ) (Phelan unpubl. data). For tautog, the maximum growth rates $\left(G_{1}\right)$ were more similar, with rates for fish in the Hudson River estuary reaching $0.024 \mathrm{~d}^{-1}$, in the nearby Navesink River $0.015 \mathrm{~d}^{-1}$ (Phelan unpubl. data) and Great Bay/Little Egg Harbor $0.020 \mathrm{~d}^{-1}$ (Able \& Hagan unpubl. data).

The growth patterns observed in this study are consistent with the distribution and abundance of juvenile fish assemblages measured concurrently in the same habitats (Able et al. 1998). The patterns of distribution and abundance of young-of-the-year winter flounder, for example, as well as other recently settled and young-of-the-year fishes that use these shallow water habitats, generally followed the habitat-specific growth trends, i.e., young-of-the-year fishes were, for the most part, rare or absent under the piers where the growth rates of winter flounder and tautog were consistently poor. While predation pressure may have affected the abundance of young fish under the piers, in the pile field and open-water sites where growth was higher, the early juvenile stages of a number of fish species including Atlantic tomcod Microgadus tomcod, winter flounder, striped bass Morone saxatilis, black sea bass Centropristis striata, and cunner Tauto- golabrus adspersus were also abundant. Thus, 2 independent measures of habitat quality (distribution and growth) suggest that under-pier areas are poor habitats for juvenile fishes.

In summary, the areas under large commercial piers do not provide high-quality habitat for young fishes, as reflected in their abundance, growth and perhaps survival. In contrast, some shallow-water habitats, even in an extensively developed, urbanized system such as the Hudson River estuary, may provide acceptable nursery habitats for young winter flounder, tautog, and other species. As a result, the varying effect of these structures should be considered when shoreline development in estuaries is planned, either as new construction or for alteration and renovation.

Postscript: While this paper was in press, subsequent caging studies have confirmed the low quality of under-pier habitats for these 2 fish species and verified that the differences in growth between the habitats studied are probably not related to food availability (Duffy-Anderson \& Able 1999).

Acknowledgements. We would like to thank J. Finn, P. Harvey, J. Johnson, S. O'Donnell, J. Rosendale and R. Wong for assistance in the field as well as D. Packer for his help with hydrographic and sediment analysis. S. Sogard provided data from earlier studies. We are also grateful to A. Bejda and B. Phelan for their valuable advice and A. Stoner for comments on an earlier draft. We thank the Army Corps of Engineers and C. Drew of the River Project for the use of their facilities. Funding for this project was provided by the Hudson River Foundation, Grant HRF no. 003/93R. This paper is Rutgers University Institute of Marine and Coastal Sciences Contribution no. 99-20

\section{LITERATURE CITED}

A.ble KW (1999) Measures of juvenile fish habitat quality: examples from a national estuarine research reserve. In: Benaka LR (ed) Fish habitat: essential fish habitat and rehabilitation. Am Fish Soc Symp 22, Bethesda, Maryland, p 134-147

Able KW, Fahay MP (1998) The first year in the life of estuarine fishes in the Middle Atlantic. Bight. Rutgers University Press, New Brunswick, NJ

Able KW, Manderson JP, Studholme AL (1996) Habitat quality in the New York/New Jersey Harbor estuary: an evaluation of pier effects on fishes. Final Report to the Hudson River Foundation, New York

Able KW, Manderson JP. Studholme AL (1998) The distribution of shallow water juvenile fishes in an urban estuary: the effects of man-made structures in the Hudson River estuary, Estuaries 21.(4b):731-744

Blaxter JHS (1970) Chap 2, Light, Part 2.3, Animals, Part 2.32. Fishes. In: Kinne $O$ (ed) Marine ecology. Vol. 1, Part 1 Wiley-Interscience, London, p 231-286

Brosnan TM, O'Shea ML (1996) Long-term improvements in water quality due to sewage abatement in the lower Hudson River. Estuaries 19(4):890-900

Chambers JR (1992) Coastal degradation and fish population 
losses. In: Stroud RH (ed) Stemming the tide of coastal fish habitat loss. Proceedings of a Symposium on Conservation of Coastal Fish Habitat, Baltimore, MD, March 7-9, 1991. National Coalition for Marine Conservation, Inc., Savannah, GA, p 45-51

Connell SD, Jones GP (1991) The influence of habitat complexity on postrecruitment processes in a temperate marine fish population. J Exp Mar Biol Ecol 151: 271-294

Deacutis C (1982) Feeding behavior of red hake and tautog and responses to oil-tainted food. PhD thesis, University of Rhode Island

Dorf BA (1994) Ecology of juvenile tautog (Tautoga onitis) in Narragansett Bay, Rhode Island. MSc thesis, University of Rhode Island

Duffy-Anderson JT, Able KW (1999) Effects of municipal piers on the growth of juvenile fish in the Hudson River estuary: a study across the pier edge. Mar Biol 133:409-418

Folk RL (1980) Petrology of sedimentary rocks. Hemphill Publishing Co, Austin, TX

Gibson RN (1994) Impact of habitat quality and quantity on the recruitment of juvenile flatfishes. Neth J Sea Res 32(2): 191-206

Grecay PA, Targett TE (1996) Effects of turbidity, light level, and prey concentration on feeding of juvenile weakfish Cynoscion regalis. Mar Ecol Prog Ser 131:11-16

Grover JJ (1982) The comparative feeding ecology of five inshore, marine fishes off Long Island, New York. PhD thesis, Rutgers University, New Brunswick, NJ

Hayse JW, Wissing TE (1996) Effects of stem density of artificial vegetation on abundance and growth of age-0 bluegills and predation by largemouth bass. Trans Am Fish Soc 125:422-433

Hoss DE, Thayer GW (1993) The importance of habitat to the early life history of estuarine dependent fishes. Am Fish Soc Symp 14:147-158

Hughes GM (1981) Affects on low oxygen and pollution on the respiratory systems of fishes. In: Pickering $A D$ (ed) Stress and fish. Academic Press, San Diego, CA, p 121-146

Hurlbert SH (1984) Pseudoreplication and the design of ecological field experiments. Ecol Mono 54: 187-211

James PL, Heck KL Jr (1994) The effects of habitat complexity and light intensity on ambush predation within a simulated seagrass habitat. J Exp Mar Biol Ecol 176:187-200

Olla BL, Wicklund R, Wilk S (1969) Behavior of winter flounder in a natural habitat. Trans Am Fish Soc 98:717-720

Pearcy WG (1962) Ecology of an estuarine population of winter flounder, Pseudopleuronectes americanus (Walbaum). Parts I-IV. Bull Bingham Oceanog Collect Yale Univ 18(1): $1-78$

Phelan BA (1992) Winter flounder movements in the inner New York Bight. Trans Am Fish Soc 121:777-784

Psuty NP, De Luca MP, Lathrop R, Able KW, Whitney S, Grassle JF (1993) The Mullica River - Great Bay National

Editorial responsibility: Kenneth Heck (Contributing Editor), Dauphin Island, Alabama, USA
Estuarine Research Reserve: a unique opportunity for reearch, preservation and management. In: Magoon OT, Wilson WS, Converse H, Tobin LT (eds) Coastal Zone 1993, Vol 2. Proceedings of the 8th Symposium on Coastal and Ocean Management. American Society of Civil Engineers, New York, p 1557-1568

Ricker WE (1975) Computation and interpretation of fish populations. Bull Fish Res Board Can 191:1-382

Scarlett PG (1991) Temporal and spatial distribution of winter flounder (Pseudopleuronectes americanus) spawning in the Navesink and Shrewsbury rivers, New Jersey. Report to New Jersey Department of Environmental Protection, Division of Fish, Game and Wildlife, Marine Fisheries Administration, Bureau of Marine Fisheries, Trenton, NJ

Sogard SM (1990) Parameters of habitat quality for epibenthic fishes and decapod crustaceans in New Jersey estuaries. PhD dissertation, Rutgers University, New Brunswick, NJ

Sogard SM (1992) Variability in growth rates of juvenile fishes in different estuarine habitats. Mar Ecol Prog Ser 85: $35-53$

Squires DF (1992) Quantifying anthropogentic shoreline modification of the Hudson River and estuary from European contact to modern time. Coastal Management 20:343-354

Stoecker RR, Collura J, Fallon PJ Jr (1992) Aquatic studies in the Hudson River Center site. In: Smith CL (ed) Estuarine research in the 1980s. The Hudson River Environmental Society, Seventh Symposium on Hudson River ecology. State University of New York Press, Albany, p 407-427

Suchanek TT (1994) Temperate coastal marine communities: biodiversity and threats. Am Zool 34:100-114

United States Department of Commerce (1992) Tide tables. 1993 National Ocean Service, Silver Spring, MD

United States Department of Commerce (1993) Tide tables. 1994 National Ocean Service, Silver Spring, MD

van der Veer HW, Berghahn R, Rinjsdorp AD (1994) Impact of juvenile growth on recruitment in flatfish. Neth J Sea Res 32: $153-173$

Vernberg WB (1997) Introduction: an overview of the effects of urbanization on estuaries: the land-estuarine interface. J Exp Mar Biol Ecol 213:ix-X

Vinyard GL, O'Brien WJ (1976) Effects of light and turbidity on the reactive distance of bluegill (Lepomis macrochirus). J Fish Res Board Can 33: 2848--2849

Weatherly AH (1972) Growth and ecology of fish populations. Academic Press, New York

Wilkerson L (1997) Systat 7.0: Statistics. SPSS Inc. Chicago, IL

Woodhead PMJ (1991) Inventory and assessment of habitat and fish resources and assessment of information on toxic effects in the New York River-New Jersey Harbor Estuary. Section 4, Tasks 5.1. Characterization and mapping of the nearshore cove areas of the New York-New Jersey Harbor Estuary. State University of New York, Stony Brook, NY

Submitted: November 13, 1997: Accepted: March 26, 1999

Proofs received from author(s): September 16, 1999 